\title{
Spor Katılımının Atılganlık ve Sportmenlik Düzeyleri İle İlişkisi
}

\author{
DOI: $10.26466 /$ opus.945546
}

\author{
Engin Efek* $-\underline{\text { Korkmaz Yiğiter }}{ }^{* *}$ \\ * Öğr. Gör., Burdur Üniversitesi, Spor Bilimleri Fakültesi, Burdur/Türkiye \\ E-Posta: \\ enginefek@gmail.com \\ ORCID: $\underline{0000-0002-7889-8151}$ \\ ** Doç. Dr., Yalova Üniversitesi, Spor Bilimleri Fakültesi, Yalova/Türkiye \\ E-Posta: korkmazyigiter@gmail.com \\ ORCID: $\underline{\text { 0000-0002-6933-3466 }}$
}

\section{Öz}

Araştırmanın amacı spora katılımın atılganlık ve sportmenlik düzeyleriyle ilişkisini incelemektir. Araştırmanın modeli için nicel araştırma türlerinden olan tarama modeli seçilmiştir. Araştırmada veri toplama süreci 2020 yılı Haziran ve Ağustos tarihleri arasında yürütülmüş ve çalışmanın evrenini 17-34 yaş arasında olup Türkiye'nin çeşitli şehirlerinde yaşayan bireyler oluşturmuştur. Çalışmanın örneklemi ise rastgele örneklem seçim tekniğgi kullanılarak araştırmaya gönüllü katılım sağlayan 1254 kişiden oluşmaktadır. Katılımcıların çeşitli demografik özelliklerini belirlemek için 5 soruluk "Kişisel Bilgi Formu", atılganlık düzeylerini belirlemek için "Rathus Atılganlık Envanteri" ve sportmenlik düzeylerini belirlemek için ise "Çok Boyutlu Sportmenlik Yönelimi Ölçeği" kullanılmıştır. Elde edilen verilerin analizi için Statistical Packadge for Social Sciences (SPSS) 17.0 paket programı kullanılmıştır. Yapılan normallik testleri (Kolmogorov-Smirnov ve Shapiro Wilk) sonucunda veriler normal dağgllm göstermediğinden Spearman Rank Korelasyon Testi, Mann Whitney-U Testi ve Kruskal Wallis Testi ve Post Hoc testlerinden Bonferroni Testi uygulanmıştır. Ayrıca, verilerin analizinde frekans, yüzde, minimum, maksimum, ortalama ve standart sapma değerleri kullanılmıştır. Anlamlılık düzeyi ise $p<0,05$ olarak belirlenmiştir. Araştırmanın bulguları katılımcıların orta derecede çekingen olmakla birlikte yüksek düzeyde sportmen davranışlara sahip olduğunu göstermiştir ve atılganlık ile sportmenlik arasında pozitif yönlü ve anlaml bir ilişki vardır. Ayrıca atılganlık ile cinsiyet, yaş, spor yaşı ve branş; sportmenlik ile cinsiyet ve branş arasında anlamlı bir ilişki vardır. Araştırmanın sonuçları bireylerde atılganlı̆̆ın arttıkça sportmenliğin de arttı̆̆ııı, cinsiyetin ve branşın atılganlık ve sportmenlik üzerinde belirleyici olduğunu göstermektedir. Diğer yandan, spor yapan bireylerin atılganlık ve sportmenlik düzeyleri de artmaktadır. Ayrıca yaş ve spor yaşı atılganlık üzerinde belirleyici olurken sportmenlik üzerinde etkili değildir.

Anahtar Kelimeler: Spora Katılım, Atılganlık, Sportmenlik. 


\title{
The Relationship between Participation in Sports and the Levels of Assertiveness and Sportsmanship
}

\begin{abstract}
The aim of the research is to examine the relationship between participation in sports and assertiveness and sportsmanship levels. The survey model, which is one of the quantitative research types, was chosen for the model of the research. The data collection process in the research was carried out between June and August 2020, and the population of the study consisted of individuals between the ages of 17-34 and living in various cities of Turkey. The sample of the study consists of 1254 people who voluntarily participated in the research using the random sample selection technique. The "Personal Information Form" with 5 questions was used to determine the various demographic characteristics of the participants, the "Rathus Assertiveness Inventory" to determine the assertiveness levels, and the "Multidimensional Sportsmanship Orientation Scale" to determine the sportsmanship levels. Statistical Packadge for Social Sciences (SPSS) 17.0 package program was used for the analysis of the obtained data. As the results of the normality tests (Kolmogorov-Smirnov and Shapiro Wilk) did not show normal distribution, the Spearman Rank Correlation Test, Mann Whitney-U Test and Kruskal Wallis Test and the Post Hoc Bonferroni Test were applied. In addition, frequency, percentage, minimum, maximum, mean and standard deviation values were used in the analysis of the data. The significance level was determined as $p<0.05$. The findings of the study showed that the participants were moderately shy, but had a high level of sportsmanship, and there was a positive and significant relationship between assertiveness and sportsmanship. In addition, there is a significant relationship between assertiveness and gender, age, sports age and branch variables. There is a significant relationship between sportsmanship and gender and branch variables. The results of the study show that as assertiveness increases, sportsmanship also increases, and gender and branch are determinants on assertiveness and sportsmanship. The assertiveness and sportsmanship levels of individuals who do sports increase. In addition, while age and sports age are determinants on assertiveness, they are not effective on sportsmanship.
\end{abstract}

Key Words: Participation in Sports, Assertiveness, Sportsmanship. 


\section{Giriş}

İlk insanlar doğa ile giriştikleri mücadelede uzun yıllar ölüm kalım savaşı vermişlerdir. Bu mücadeleler çoğu zaman avlanma, kaçma ve kovalama şeklinde olmuştur. Spor olgusu sonraki dönemlerde zaman zaman amaç değiştirmiş; kimi zaman savaşa yönelik birtakım hareketlerin barışçıl bir rekabet ile yapıldığı, kimi zaman eğitim amaçlı uygulanan hareketlerin sağlıklı bir yaşam reçetesine dönüştüğ̈ bir olgu haline gelmiştir. İnsan nasıl sürekli olgunlaşıp gelişiyor ise spor da çok eski tarihlere kadar uzanmakta ve gelişimini devam ettirmektedir (Efek, 2020). Günümüzde ise küresel bir yapıya kavuşan spor bilim, teknik ve entelektüelite gibi olgulardan daha geniş bir tabana oturarak etki alanını genişletmiştir (Çaha, 1999; Erkal, 1981; Sunay, 2017). Dolayısıyla spor gelişmiş toplumların en yaygın ve en etkili sosyal kurumlarından biri haline gelerek karşımıza çıkmaktadır (Yetim, 2000).

İlgili alanyazın incelendiğinde sporun birçok tanımının yapıldığ görülmekte ve fiziksel anlamda birçok faydasının olduğu ifade edilmektedir. Diğer yandan sporun yalnızca fiziksel anlamda değil sosyal ve toplumsal anlamda da faydalarının olduğu (Zorba ve Göksel, 2016) bilinen bir gerçektir. Fiziksel etkinlikler yoluyla kişilerin gelişen sosyal ilişkileri (Chang, Wray ve Lin, 2014; Chang vd., 2018; Ertüzün, Hadi ve Fidan, 2020), gelişen fiziksel ve zihinsel sağlıkları (Yeh, Chang ve Lai, 2017) alanyazına sık sık konu edilmiştir. Sportmenlik kavramı da spor olgusu içerisinde ifade edilmekte olup en bilinen anlamıla "fair play" veya "centilmenlik"tir (Certel, Bahadır ve Çelik, 2020; Pehlivan, 2004). Sportmenlik kavramı ahlak, adalet, felsefe, sayg1 ve etik kurallarının bir bağlamı olarak ifade edilirken kurallara uymama, hile yapma, uygunsuz davranışlar sergileme ve toplumlar tarafından kabul görmeyen yalan söyleme gibi bazı davranışları reddetmektedir (Greni, 1997; Yapan, 2007). Kısacası sportmenlik spor alanında ahlaki açıdan kabul edilebilir tutum veya davranışlar (Cremades, 2014; Efek, 2019) olarak ifade edilebilir. Kavramsal açıdan bakıldığında yine spor yoluyla geliştirilebilir bir davranış olan atılganlık Wolpe ve Lazarus (1966) tarafından ilk kez ortaya atılmıştır. Kısaca atılganlık tanımı; kişilerin sadece içsel eylemleri açısından değil aynı zamanda farklı bireylerle ilgili 
davranış ve tutumlarında da hoşgörü ve saygı çerçevesinde dostane bir tavırla yaklaşımda bulunmasını ifade etmek amacıyla kullanılmaktadır.

Literatürde sportmenlik ve atılganlık ile ilgili birçok çalışmanın yapıldığ 1 görülmektedir. Özellikle spora katılım yoluyla sportmenliğin ve atılganlığın geliştirilebildiği düşünüldügüunde bu araştırmalar farklı türden örneklemler ve değişkenlerle birçok araştırmaya konu edilmiştir. Mathner vd. (2010)'nin, Mendez vd. (2015)'nin, Mouratiodu, Goutza ve Chatzopoulos (2007)'un, Proios, Doganis ve Proios (2006)'un, Karafil vd. (2017)'nin ve Yalız Solmaz ve Bayrak (2016)'ın yapmış olduğu çalışmalar sporun sportmenlik üzerindeki olumlu etkisini ortaya koymuştur. Yine aynı şekilde Newman (2003)'ın, Etzel-Wise ve Mears (2004)'ın, Ryan ve Dzewaltowski (2002)'nin, Gönener (2020)'in, ve Çam vd. (2010)'nin yapmış olduğu çalışmalar da spora katılımın atılganlık üzerindeki olumlu etkisini ortaya koymuştur. Atılganlık, kabul edilen bir davranış sayılan kişinin başkalarına dostça yaklaşımları olarak ifade edilirken sportmenlik kavramı açısından pozitif davranışlar sergileme ile ilişkilendirilebilir. Dolayısıyla sportmenlik ve atılganlık kavramları birbirlerini etkileyebilecek kavramlar olarak düşünülebilir. Literatürde sportmenlik ve atılganlık kavramlarının spora katılım açısından birlikte ele alındığı bir çalışmaya rastlanmamasından dolayı bu araştırma önem arz etmekle birlikte bu çalışmadan elde edilecek sonuçlar alana katkı sağlayacaktır. Bu çalışmayla spora katılımın atılganlık ve sportmenlik ile ilişkisine farklı ve daha geniş bir örneklem grubuyla bir kez daha bakmanın yanı sıra ilk kez atılganlık ve sportmenlik kavramlarının birlikte ele alınacak olması bu çalışmanın önemini ifade etmektedir. Giderek küreselleşen ve büyüyen spor ortamına paralel bir şekilde artan ahlak dışı davranışların azaltılması ve bireylerin hem kendi hem de karşılarındaki kişilerin hak ve hukukunu gözetecek davranışlarda bulunması önemlidir. Dolayısıyla hem spor için hem de bireylerin gündelik hayatı için sporun bu iki parametreye katkısını ortaya koymak bu çalışmanın diğer bir önemini ifade etmektedir.

$\mathrm{Bu}$ araştırmanın amacı, spora katılımın atılganlık ve sportmenlik düzeyleriyle ilişkisini incelemektir. Bu amaçla yapılan araştırmada; çalışmaya katılanların ölçek sorularını içtenlikle yanıtladıkları, çalışma için seçilen örneklemin evreni temsil ettiği ve kullanılan ölçeklerin katılımcıların atılganlık ve sportmenlik düzeylerini ölçebilir niteliğe 
sahip olduğu varsayılmıştır. Araştırmada elde edilen veriler kullanılan ölçeklerle ve araştırmaya gönüllü olarak katılanlarla sınırlandırılmıştır. Spora katılımın atılganlık ve sportmenlik ile ilişkisinde cinsiyet, yaş, spor yaşı ve branş değişkenlerinin etkisi olabileceği düşünülerek araştırma için bazı hipotezler oluşturulmuştur. Bu hipotezler aşağıdaki gibidir:

$\mathrm{H}_{1}$ : Atılganlık ile sportmenlik arasında pozitif yönlü ve anlamlı bir ilişki vardır.

$\mathrm{H}_{2}$ : Atılganlık ile cinsiyet arasında anlamlı bir ilişki vardır.

$\mathrm{H}_{3}$ : Sportmenlik ile cinsiyet arasında anlamlı bir ilişki vardır.

$\mathrm{H}_{4}$ : Spora katılım gösterenlerin atılganlık düzeyleri daha yüksektir.

H5: Spora katılım gösterenlerin sportmenlik düzeyleri daha yüksektir.

$\mathrm{H}_{6}$ : Atılganlık ile yaş arasında anlamlı bir ilişki vardır.

H7: Sportmenlik ile yaş arasında anlamlı bir ilişki vardır.

H8: Atılganlık ile spor yaşı arasında anlamlı bir ilişki vardır.

H9: Sportmenlik ile spor yaşı arasında anlamlı bir ilişki vardır.

$\mathrm{H}_{10}$ : Atılganlık ile branş arasında anlamlı bir ilişki vardır.

H11: Sportmenlik ile branş arasında anlamlı bir ilişki vardır.

\section{Yöntem}

Katılımcılar: Araştırmanın modeli için nicel araştırma türlerinden olan tarama modeli seçilmiştir. Araştırmanın evrenini 2020 yılında Türkiye'nin çeşitli şehirlerinde bulunan ve spora katılım gösteren ve göstermeyen kişiler oluştururken örneklemini ise bu evren içinden rastgele tesadüfi yöntemle seçilmiş 1254 kişi oluşturmuştur. Araştırma için Düzce Üniversitesi Araştırma ve Yayın Etik Kurulu biriminden izin alınmıştır (2021/15). 
Tablo 1. Katılımcıların Çeşitli Demografik Özellikleri

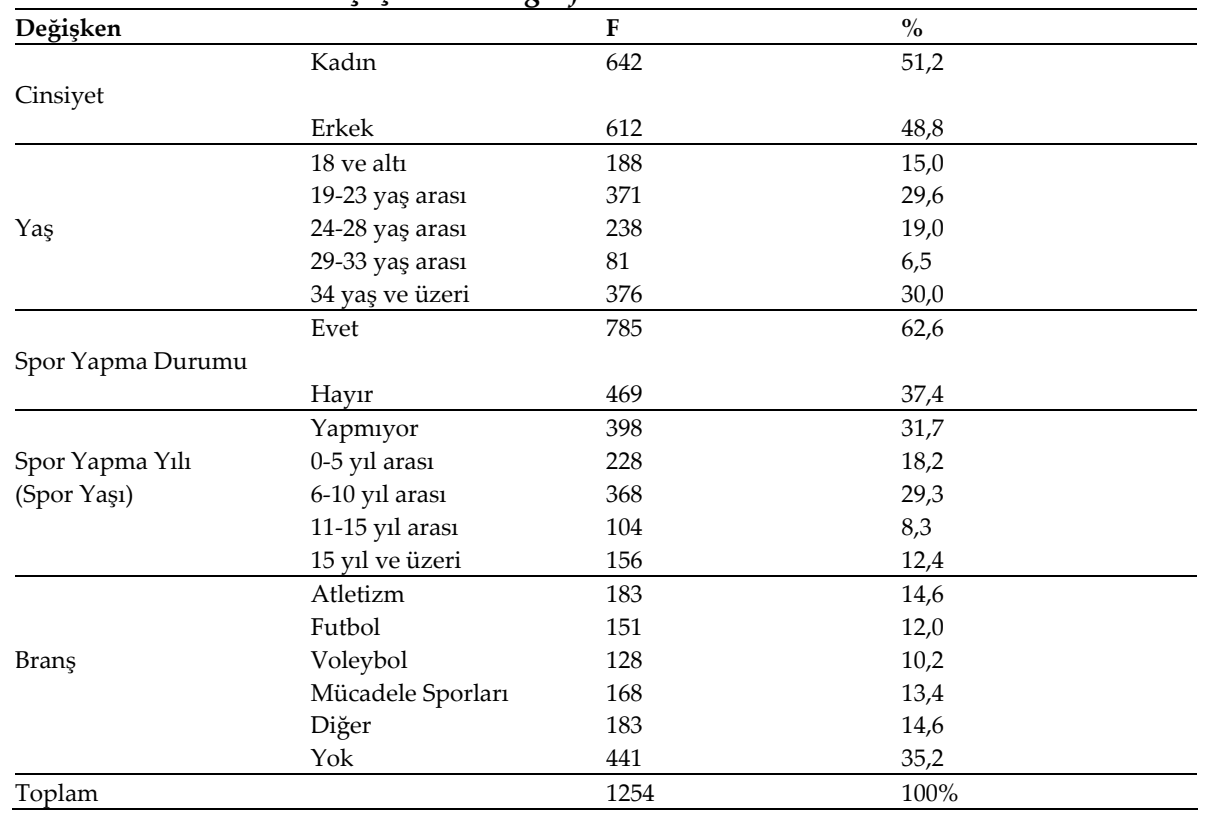

Veri Toplama Araçları: Yapılan araştırmada 3 farklı veri toplama aracı kullanılmıştır. Katılımcıların çeşitli demografik özelliklerini (cinsiyet, spora katılım, yaş, spor yaşı ve branş) belirlemek için araştırmacılar tarafından oluşturulan 5 soruluk "Kişisel Bilgi Formu" kullanılmıştır. Katılımcıların atılganlık düzeylerini belirlemek için Rathus (1973) tarafından geliştirilen ve Voltan (1980) tarafından Türkçe uyarlaması yapılan "Rathus Atılganlı Envanteri" kullanılmıştır. Katılımcıların sportmenlik düzeylerini belirlemek için ise Vallerand vd. (1997) tarafından geliştirilen ve Sezen Balçıkanlı (2010) tarafından Türkçeye uyarlanan "Çok Boyutlu Sportmenlik Yönelimi Ölçeği” kullanılmıştır.

Rathus Atılganlik Envanteri: Rathus (1973) tarafından geliştirilen "Rathus Atılganlık Envanteri" Voltan (1980) tarafından Türkçeye uyarlanmıştır. Envanter iki şekilde puanlanmaktadır. İlki, -3 'ten +3 'e doğru sıralanmış şekilde 6 likertli olarak kullanılmaktadır. Alınacak toplam puan -90 ile +90 arasında değişmektedir. -90 en yüksek çekingenliği, +90 ise en yüksek atılganlığı belirtmektedir. İkinci 
puanlama sisteminde ise her maddeye 1-6 arasinda puan verilmektedir. $3,6,7,8,10,18,20,21,22,25,27,28$ ve 29 . maddeler (13 madde) olumlu ifadeleri; $1,2,4,5,9,11,12,13,14,15,16,17,19,23,24,26$ ve 30 . maddeler (17 madde) ise olumsuz ifadeleri belirtmektedir. İfadeler sirası ile 1-6 arasında puanlanır ve olumlu ifadeler ters çevrilir. Olumlu ve olumsuz ifadelerin toplamindan elde edilen puan envanterin toplam puanını vermektedir. Çekingenliğe doğru uzanan uç 30 puan, atılganlığa doğru uzanan uç puan ise $180^{\prime}$ dir. Puanlama yapılırken atılganlık düzeyi; 30-80 puan arası çekingen, 80-130 puan arası orta derecede çekingen ve 130-180 puan arası ise atılgan özellik olarak ifade edilmiştir. Voltan (1980), envanterin alfa tutarlılık katsayısını 0.70, test-tekrar test güvenilirliğini ise 0.92 olarak bulmuştur.

Çok Boyutlu Sportmenlik Yönelimi Ölçeği: Vallerand vd. (1997) tarafından geliştirilen ve Sezen Balçıkanlı (2010) tarafından Türkçeye uyarlanan "Çok Boyutlu Sportmenlik Yönelimi Ölçeği" orijinalinde 25 maddeden ve 5 faktörden oluşan 5'li likert tipi bir ölçektir. Orijinal ölçeğin alt faktörlerini "Sosyal Normlara Uyum", "Kurallara ve Yönetime Sayg1", "Sporda Sorumluluklara Bağlllık", "Rakibe Saygı" ve "Negatif Yaklaşımlar" faktörleri oluşturmaktadır. Türkçeye uyarlama çalışmaları yapılırken "Negatif Yaklaşımlar" alt faktörünün çalışmadığı gözlenmiş ve bu yüzden bu faktör ve maddeleri orijinal ölçekten çıkarılmıştır. Türkçe uyarlaması yapılan ölçek 4 faktörden ve 20 maddeden oluşmaktadır. Ölçekten alınabilecek minimum puan 20 ve maksimum puan 100'dür. Faktörler şöyledir: Sosyal Normlara Uyum (Madde 1, 2, 3, 4, 5). Kurallar ve Yönetime Sayg1 (Madde 6, 7, 8, 9, 10). Sporda Sorumluluklara Bağlılık (Madde 11, 12, 13, 14, 15). Rakibe Sayg1 (Madde 16, 17, 18, 19, 20). Cronbach Alpha değerleri; Faktör 1 (Sosyal Normlara Uyum) 0,86; Faktör 2 (Kurallara ve Yönetime Sayg1) 0,83; Faktör 3 (Sporda Sorumluluklara Bağlllık) 0,91; Faktör 4 (Rakibe Sayg1) 0,82 'dir. Değerler, yüksek derecede güvenilir olarak bulunmuştur. Buna göre, ölçeğin Türkçe uyarlaması geçerli ve güvenilir bir yapıya sahiptir. 


\section{Veri Analizi}

Elde edilen verilerin analizi için Statistical Packadge for Social Sciences (SPSS) 17.0 paket programı kullanılmıştır. Yapılan normallik testleri (Kolmogorov-Smirnov ve Shapiro Wilk) sonucunda ölçeklerden elde edilen puanların normal dağılım göstermediği belirlenmiştir. Bu sebeple çalışmada parametrik olmayan testlerden Spearman Rank Korelasyon Testi, Mann Whitney-U Testi ve Kruskal Wallis Testi ve çözümleme sonucunda gruplar arasında bulunan anlamlı farkın hangi gruptan kaynaklandığını belirlemek için ise Post Hoc testlerinden Bonferroni Testi uygulanmıştır. Ayrıca, verilerin analizinde frekans, yüzde, minimum, maksimum, ortalama ve standart sapma değerleri kullanılmıştır. Anlamlılık düzeyi ise $\mathrm{p}<0,05$ olarak belirlenmiştir.

Tablo 2. Rathus Atılganlık Envanteri ve Çok Boyutlu Sportmenlik Yönelimi Ölçeği'nin Toplam Puanlarna Ait Kolmogorov-Smirnov ve Shapiro-Wilk Normallik Testleri

\begin{tabular}{lllllll}
\hline \multicolumn{4}{c}{ Kolmogorov-Smirnov $^{\mathbf{a}}$} & \multicolumn{3}{c}{ Shapiro-Wilk } \\
\hline & İstatistik & df & p & İstatistik & df & p \\
\hline Rathus Atılganlik Envanteri &, 055 & 1254 &, $\mathbf{0 0 0}$ &, 989 & 1254 & $\mathbf{0 0 0}^{*}$ \\
Sportmenlik &, 094 & 1254 &, $\mathbf{0 0 0}^{*}$ &, 858 & 1254 & $\mathbf{, 0 0 0}^{*}$ \\
\hline
\end{tabular}

$*(p<0,05)$.

Yapılan testler incelendiğinde ölçeklerden elde edilen toplam puanların normal dağılım göstermediği $(\mathrm{p}<0.05)$ görülmektedir.

\section{Bulgular}

Spora katılımın atılganlık sportmenlik düzeyleriyle ilişkisini belirlemek amacıyla yapılan araştırmanın bu bölümünde betimsel istatistik testi, $\mathrm{t}$ testi ve anova testi sonuçlarına tablolar halinde yer verilmiştir. 
Tablo 3. Atılganlık Ölçeği ve Sportmenlik Ölçeğinden Alınan Puanlara Ait Istatistikler

\begin{tabular}{llllll}
\hline Ölçek & N & Min & Maks & Ort & Ss \\
\hline Atılganlık & 1254 & 60,00 & 179,00 & 119,5104 & 20,85662 \\
Sportmenlik Toplam & 1254 & 20,00 & 100,00 & 86,2687 & 10,45136 \\
$\begin{array}{l}\text { Sosyal Normlara Uyum } \\
\text { Kurallar ve Yönetimem }\end{array}$ & 1254 & 5,00 & 25,00 & 21,7959 & 3,61249 \\
$\begin{array}{l}\text { Saygi } \\
\text { Sosyal Sorumluluklara }\end{array}$ & 5,00 & 25,00 & 20,6388 & 3,16724 \\
$\begin{array}{l}\text { Bağlllık } \\
\text { Rakibe Sayg1 }\end{array}$ & 5,00 & 25,00 & 22,6372 & 2,95482 \\
\hline
\end{tabular}

Tablo 3 incelendiğinde, katılımcıların ölçeklerden aldıkları puanlara ait istatistiksel bilgiler görülmektedir. Buna göre katılımcıların atılganlık ölçeğinden aldıkların puanların ortalaması 119,5104 ve sportmenlik ölçeğinin toplam puanından aldıkları puanların ortalaması ise 86,2687 'dir. Çok boyutlu sportmenlik yönelimi ölçeğinin sosyal normlara uyum alt ölçeğinden aldıkları puanların ortalaması 21.7959; kurallar ve yönetime saygı alt boyutundan aldıkları puanların ortalaması 20.6388; sosyal sorumluluklara bağlılık alt ölçeğinden aldıkları puanların ortalaması 22,6372 ve rakibe saygı alt ölçeğinden aldıkları puanların ortalaması ise 21.1970 olarak belirlenmiştir.

Tablo 4. Atılganlık Ölçeği, Sportmenlik Ölçeği ve Sportmenlik Ölçeği Alt Boyutlarından Alnan Puanlar Arasındaki İlişki (Spearman Korelasyon Analizi)

\begin{tabular}{|c|c|c|c|c|c|c|c|}
\hline & & $\begin{array}{l}\text { RAE } \\
\text { Toplam }\end{array}$ & $\begin{array}{l}\text { Sportm. } \\
\text { Toplam }\end{array}$ & SNU & KYS & SSB & RS \\
\hline \multirow{3}{*}{ RAE Toplam } & Korelasyon & 1,000 &, $153^{* *}$ & $108^{* *}$ & ,004 &, $257^{* *}$ & $126^{* *}$ \\
\hline & $\mathrm{p}$ & . &, $000^{*}$ &, $000^{*}$ & ,892 &, $000^{*}$ &, $000^{*}$ \\
\hline & $\mathrm{N}$ & 1254 & 1254 & 1254 & 1254 & 1254 & 1254 \\
\hline \multirow{3}{*}{$\begin{array}{l}\text { Sportmenlik } \\
\text { Toplam }\end{array}$} & Korelasyon &, $153^{* *}$ & 1,000 & $808^{* *}$ &, $747^{* *}$ & ,700** &, $757^{* *}$ \\
\hline & $\mathrm{p}$ &, $000^{*}$ & . &, $000^{*}$ &, $000^{*}$ &, $000^{*}$ &, $000^{*}$ \\
\hline & $\mathrm{N}$ & 1254 & 1254 & 1254 & 1254 & 1254 & 1254 \\
\hline \multirow{3}{*}{$\begin{array}{l}\text { Sosyal Normlara } \\
\text { Uyum }\end{array}$} & Korelasyon & $108^{* *}$ &, $808^{* *}$ & 1,000 &, $517^{* *}$ &, $472^{* *}$ & $468^{* *}$ \\
\hline & $\mathrm{p}$ &, $000^{*}$ &, $000^{*}$ & . &, $000^{*}$ &, $000^{*}$ &, $000^{*}$ \\
\hline & $\mathrm{N}$ & 1254 & 1254 & 1254 & 1254 & 1254 & 1254 \\
\hline \multirow{3}{*}{$\begin{array}{l}\text { Kurallar ve } \\
\text { Yönetime Sayg1 }\end{array}$} & Korelasyon & ,004 &, $747^{* *}$ &, $517^{* *}$ & 1,000 &, $397^{* *}$ &, $409^{* *}$ \\
\hline & $\mathrm{p}$ & ,892 &, $000^{*}$ &, $000^{*}$ & . &, $000^{*}$ &, $000^{*}$ \\
\hline & $\mathrm{N}$ & 1254 & 1254 & 1254 & 1254 & 1254 & 1254 \\
\hline
\end{tabular}




\begin{tabular}{|c|c|c|c|c|c|c|c|}
\hline \multirow{3}{*}{$\begin{array}{l}\text { Sosyal } \\
\text { Sorumluluklara } \\
\text { Bağll1lk }\end{array}$} & Korelasyon & $257^{* *}$ & ,700** & ,472** & ,397** & 1,000 & 416 \\
\hline & $\mathrm{p}$ &, $000^{*}$ &, $000^{*}$ &, $000^{*}$ &, $000^{*}$ & . &, $000^{*}$ \\
\hline & $\mathrm{N}$ & 1254 & 1254 & 1254 & 1254 & 1254 & 1254 \\
\hline \multirow{3}{*}{ Rakibe Saygı } & Korelasyon &, $126^{* *}$ & ,757** & ,468 & ,409** &, $416^{* *}$ & 1,000 \\
\hline & $\mathrm{p}$ &, $000^{*}$ &, $000^{*}$ &, $000^{*}$ &, $000^{*}$ &, $000^{*}$ & . \\
\hline & $\mathrm{N}$ & 1254 & 1254 & 1254 & 1254 & 1254 & 1254 \\
\hline
\end{tabular}

$*(p<0,05)$.

Tablo 4'te atılganlık ölçeği, sportmenlik ölçeği ve sportmenlik ölçeğinin alt boyutları puanları arasındaki ilişkiler incelendiğinde;

Atılganlık ile sportmenlik arasında pozitif yönlü ve anlamlı ( $\mathrm{r}=, 153$; $\mathrm{p}<0,05)$; atılganlık ile sosyal normlara uyum alt boyutu arasında pozitif yönlü ve anlamlı $(\mathrm{r}=, 108 ; \mathrm{p}<0,05)$; atılganlık ile kurallar ve yönetime sayg1 alt boyutu arasında pozitif yönlü ve anlamlı $(r=, 004 ; \mathrm{p}<0,05)$; atılganlık ile sosyal sorumluluklara bağlılık alt boyutu arasında pozitif yönlü ve anlamlı $(r=, 257 ; \mathrm{p}<0,05)$ ve atılganlık ile rakibe saygı alt boyutu arasında pozitif yönlü ve anlamlı $(\mathrm{r}=, 126 ; \mathrm{p}<0,05)$ ilişkiler tespit edilmiştir.

Tablo 5. Katılımcıların Atılganlık, Sportmenlik ve Sportmenlik Ölçeğinin Alt Boyutlarından Aldıkları Puanların Cinsiyete Göre Mann Whitney-U Testi ile Karşılaştırılması

\begin{tabular}{|c|c|c|c|c|c|}
\hline Puan & Cinsiyet & $\mathbf{N}$ & Sira Ortalaması & $\mathrm{Z}$ & $\mathbf{P}$ \\
\hline \multirow[t]{2}{*}{ Atılganlık } & Kadın & 642 & 600,90 & $-2,665$ & , $008^{*}$ \\
\hline & Erkek & 612 & 655,41 & & \\
\hline \multirow[t]{2}{*}{ Sportmenlik } & Kadın & 642 & 678,23 & $-5,084$ & , $000^{*}$ \\
\hline & Erkek & 612 & 574,29 & & \\
\hline Sosyal Normlara & Kadın & 642 & 671,04 & $-4,521$ & , $000^{*}$ \\
\hline Uyum & Erkek & 612 & 581,82 & & \\
\hline Kurallar ve & Kadın & 642 & 672,05 & $-4,492$ & , $000^{*}$ \\
\hline Yönetime Saygi & Erkek & 612 & 580,77 & & \\
\hline Sosyal Soruml. & Kadın & 642 & 651,46 & $-2,492$ & , $013^{*}$ \\
\hline Bağlılık & Erkek & 612 & 602,36 & & \\
\hline \multirow[t]{2}{*}{$\overline{\text { Rakibe Sayg1 }}$} & Kadın & 642 & 660,15 & $-3,301$ & ,001* \\
\hline & Erkek & 612 & 593,25 & & \\
\hline
\end{tabular}

$*(p<0,05)$.

Tablo 5'e göre katılımcların cinsiyetleri ile atılganlık, sportmenlik, sosyal normlara uyum, kurallar ve yönetime sayg1, sosyal sorumluluklara bağlılık ve rakibe saygı düzeyleri arasında anlamlı bir ilişkinin olduğu görülmektedir $(p<0,05)$. Kadınların algılanan stres, 
sportmenlik, sosyal normlara uyum, kurallar ve yönetime sayg1, sosyal sorumluluklara bağlılık ve rakibe saygı düzeyleri erkeklere göre daha yüksektir. Erkeklerin ise atılganlık düzeyleri kadınlara göre daha yüksek bulunmuştur.

Tablo 6. Katılımcıların Atılganlık, Sportmenlik ve Sportmenlik Ölçeğinin Alt Boyutlarından Aldıkları Puanların Spor Yapma Değişkenine Göre Mann Whitney-U Testi ile Karşılaştırılması

\begin{tabular}{lccccc}
\hline Puan & Spor Yapma & N & Sira Ortalamasi & Z & P \\
\hline Atılganlık & Evet & 785 & 667,62 & $-5,076$ &, $\mathbf{0 0 0}$ \\
& Hayır & 469 & 560,35 & & \\
Sportmenlik & Evet & 785 & 632,90 &,- 684 &, 494 \\
& Hayrr & 469 & 618,46 & & \\
Sosyal Normlara & Evet & 785 & 639,35 & $-1,555$ &, 120 \\
Uyum & Hayır & 469 & 607,66 & & \\
Kurallar ve & Evet & 785 & 620,79 &,- 855 &, 393 \\
Yönetime Sayg1 & Hayır & 469 & 638,73 & & \\
Sosyal Soruml. & Evet & 785 & 659,50 & $-4,205$ &, $\mathbf{0 0 0}$ \\
Bağll1lk & Hayır & 469 & 573,94 & & \\
Rakibe Sayg1 & Evet & 785 & 611,32 & $-2,066$ &, $\mathbf{0 3 9}$ \\
& Hayır & 469 & 654,58 & & \\
\hline
\end{tabular}

$*(p<0,05)$.

Tablo 6 incelendiğinde katılımciların spor yapma durumları ile atılganlık, sosyal sorumluluklara bağlılık ve rakibe saygı düzeyleri arasında anlamlı bir ilişkinin olduğu tespit edilmiştir $(p<0,05)$. Spor yapma durumu ile sportmenlik, sosyal normlara uyum ve kurallar ve yönetime saygı düzeyleri arasında ise herhangi bir anlamlı ilişki yoktur $(\mathrm{p}>0,05)$. Spor yapanların atılganlık, sportmenlik, sosyal normlara uyum ve sosyal sorumluluklara bağlılık düzeyleri spor yapmayanlara göre daha yüksektir. Spor yapmayanların ise kurallar ve yönetime saygı ve rakibe saygı düzeyleri spor yapanlara göre daha yüksek tespit edilmiştir. 
Tablo 7. Katılımcıların Atılganlık, Sportmenlik ve Sportmenlik Ölçeğinin Alt Boyutlarından Aldıkları Puanların Yaş Değişkenine Göre Kruskal Wallis Testi ile Karşılaştırılması

\begin{tabular}{|c|c|c|c|c|c|c|c|}
\hline Puan & Yaş & n & $\begin{array}{c}\text { Siralar } \\
\text { Ort }\end{array}$ & $\mathrm{X}^{2}$ & sd & $\mathrm{p}$ & Bonferroni \\
\hline \multirow{5}{*}{ Atılganlık } & 18 ve altı & 188 & 692,51 & & & & \\
\hline & 19-23 yaş arası & 371 & 561,83 & & & & $1>2$ \\
\hline & $24-28$ yaş arası & 238 & 678,00 & 23,103 & 4 &, $000 *$ & $1>5$ \\
\hline & $29-33$ yaş arası & 81 & 644,40 & & & & $3>2$ \\
\hline & 34 yaş ve üzeri & 376 & 624,19 & & & & \\
\hline \multirow{5}{*}{ Sportmenlik } & 18 ve altı & 188 & 631,88 & & & & \\
\hline & 19-23 yaş arası & 371 & 596,03 & & & & \\
\hline & $24-28$ yaş arası & 238 & 664,53 & 5,447 & 4 & ,244 & \\
\hline & $29-33$ yaş arası & 81 & 623,66 & & & & \\
\hline & 34 yaş ve üzeri & 376 & 633,75 & & & & \\
\hline \multirow{5}{*}{$\begin{array}{l}\text { Sosyal Normlara } \\
\text { Uyum }\end{array}$} & 18 ve altı & 188 & 646,43 & & & & \\
\hline & 19-23 yaş arası & 371 & 603,20 & & & & \\
\hline & $24-28$ yaş arası & 238 & 683,57 & 9,600 & 4 &, $048^{*}$ & $3>2$ \\
\hline & 29-33 yaş arası & 81 & 607,45 & & & & \\
\hline & 34 yaş ve üzeri & 376 & 610,85 & & & & \\
\hline \multirow{5}{*}{$\begin{array}{l}\text { Kurallar ve } \\
\text { Yönetime Sayg1 }\end{array}$} & 18 ve altı & 188 & 586,55 & & & & \\
\hline & $19-23$ yaş arası & 371 & 631,88 & & & & \\
\hline & $24-28$ yaş arası & 238 & 602,67 & 8,542 & 4 & ,074 & \\
\hline & $29-33$ yaş arası & 81 & 596,56 & & & & \\
\hline & 34 yaş ve üzeri & 376 & 666,04 & & & & \\
\hline \multirow{5}{*}{$\begin{array}{l}\text { Sosyal Soruml. } \\
\text { Bağlılık }\end{array}$} & 18 ve altı & 188 & 711,66 & & & & \\
\hline & 19-23 yaş arası & 371 & 641,27 & & & & $1>5$ \\
\hline & $24-28$ yaş arası & 238 & 655,36 & 27,080 & 4 &, $000 *$ & $2>5$ \\
\hline & 29-33 yaş arası & 81 & 588,27 & & & & \\
\hline & 34 yaş ve üzeri & 376 & 562,66 & & & & \\
\hline \multirow{5}{*}{ Rakibe Sayg1 } & 18 ve altı & 188 & 600,16 & & & & $5>1$ \\
\hline & 19-23 yaş arası & 371 & 555,91 & & & & $3>2$ \\
\hline & $24-28$ yaş arası & 238 & 653,73 & 28,373 & 4 &, $000 *$ & $4>2$ \\
\hline & $29-33$ yaş arası & 81 & 666,94 & & & & $5>2$ \\
\hline & 34 yaş ve üzeri & 376 & 686,71 & & & & \\
\hline
\end{tabular}

$*(p<0,05)$.

Tablo 7'ye göre katılımcıların yaşları ile atılganlık, sosyal normlara uyum, sosyal sorumluluklara bağlılık ve rakibe saygı düzeyleri arasında anlamlı bir ilişkinin olduğu tespit edilmiştir $(p<0,05)$. Yaş değişkeni ile sportmenlik ve kurallar ve yönetime saygı düzeyi arasında ise herhangi bir anlamlı farklılık yoktur ( $>>0,05)$. Anlamlı farklılı̆̆ın hangi gruplar arasında olduğunu belirlemek için yapılan Bonferroni testi sonucuna göre atılganlık düzeylerine bakıldığında, 18 ve altı yaş grubundaki katılımcıların atılganlık düzeyleri 19-23, 34 yaş ve üzerine göre ve 24-28 yaş grubundaki katılımcıların atılganlık düzeyleri de 19-23 yaş 
arasındaki katılımcılara göre anlamlı derecede daha yüksektir. Ayrıca atılganlık düzeyi en yüksek olan yaş grubu 18 ve altı; en düşük olan yaş grubu ise 19-23 yaş grubudur. Sosyal normlara uyum düzeylerine bakıldığında, 24-28 yaş arasında olan katılımcıların sosyal normlara uyum düzeyi 19-23 yaş arasında olan katılımcılara göre anlamlı derecede daha yüksektir. Sosyal sorumluluklara bağlılık düzeylerine bakıldığında, 18 yaş ve altında olan katılımcıların sosyal sorumluluklara bağlılık düzeyi 34 yaş ve üzerinde olan ve 19-23 yaş arasında olan katılımcıların sosyal sorumluluklara bağlllık düzeyi 34 yaş ve üzerinde olan katılımcılara göre anlamlı derecede daha yüksektir. Rakibe sayg1 düzeylerine bakıldığında ise, 34 yaş ve üzeri, 29-33 yaş arası ve 24-28 yaş arası olan katılımcıların rakibe saygı düzeyleri 19-23 yaş arasında olan katılımcılara göre anlamlı derecede daha yüksektir. Ayrıca 34 yaş ve üzeri olan katılımcların rakibe saygı düzeyleri 18 yaş ve altında olan katılımcılara göre daha yüksek bulunmuştur.

Tablo 8. Katılımcıların Atılganlık, Sportmenlik ve Sportmenlik Ölçeğinin Alt Boyutlarından Aldıkları Puanların Spor Yaşı Değgişkenine Göre Kruskal Wallis Testi ile Karşılaştırılması

\begin{tabular}{|c|c|c|c|c|c|c|c|}
\hline Puan & Spor Yaşı & $\mathbf{n}$ & Siralar Ort & $\mathrm{X}^{2}$ & sd & $\mathrm{p}$ & Bonferroni \\
\hline & & & & & & & $3>1$ \\
\hline & Spor Yapmiyor & 398 & 548,32 & & & & $4>1$ \\
\hline & $0-5$ yıl arası & 228 & 601,63 & & & & $5>1$ \\
\hline \multirow[t]{7}{*}{ Atılganlık } & 6-10 yıl arası & 368 & 631,92 & 57,814 & 4 &, $000^{*}$ & $4>2$ \\
\hline & $11-15$ yıl arası & 104 & 764,78 & & & & $4>3$ \\
\hline & 16 yıl ve üzeri & 156 & 765,69 & & & & $5>2$ \\
\hline & & & & & & & $5>3$ \\
\hline & & & & & & & $5>4$ \\
\hline & Spor Yapmiyor & 398 & 607,92 & & & & \\
\hline & $0-5$ yil arası & 228 & 625,48 & & & & \\
\hline \multirow[t]{4}{*}{ Sportmenlik } & 6-10 yıl arası & 368 & 630,06 & 5,730 & 4 & 220 & \\
\hline & $11-15$ yıl arası & 104 & 702,98 & & & & \\
\hline & 16 yıl ve üzeri & 156 & 624,05 & & & & \\
\hline & Spor Yapmiyor & 398 & 613,19 & & & & \\
\hline Sosyal Normlara & 0-5 yıl arası & 228 & 637,02 & & & & \\
\hline \multirow[t]{4}{*}{ Uyum } & 6-10 yıl arası & 368 & 611,42 & 12,622 & 4 &, $013^{*}$ & $4>3$ \\
\hline & $11-15$ yıl arası & 104 & 739,77 & & & & \\
\hline & 16 yıl ve üzeri & 156 & 613,17 & & & & \\
\hline & Spor Yapmiyor & 398 & 624,27 & & & & \\
\hline Kurallar ve & $0-5$ yıl arası & 228 & 623,56 & & & & \\
\hline \multirow[t]{4}{*}{ Yönetime Saygı } & $6-10$ yıl arası & 368 & 627,34 &, 570 & 4 & ,966 & \\
\hline & $11-15$ yıl arası & 104 & 652,54 & & & & \\
\hline & 16 yıl ve üzeri & 156 & 625,19 & & & & \\
\hline & Spor Yapmiyor & 398 & 547,95 & & & & \\
\hline Sosyal Soruml. & 0-5 yıl arası & 228 & 673,11 & & & & $2>1$ \\
\hline
\end{tabular}




\begin{tabular}{lccccccc}
\hline Bağlılık & 6-10 yıl arası & 368 & 683,06 & 34,148 & 4 &, $000^{*}$ & $3>1$ \\
& $11-15$ yıl arası & 104 & 641,47 & & & & $3>5$ \\
& 16 yıl ve üzeri & 156 & 623,42 & & & & \\
\hline & Spor Yapmiyor & 398 & 656,16 & & & & \\
Rakibe Sayg1 & $0-5$ yıl arası & 228 & 600,95 & & & & \\
& $6-10$ yıl arası & 368 & 604,01 & 6,153 & 4 &, 188 & \\
& $11-15$ yıl arası & 104 & 658,63 & & & & \\
& 16 yıl ve üzeri & 156 & 627,85 & & & & \\
\hline
\end{tabular}

$*(p<0,05)$.

Tablo 8'e göre katılımcıların spor yaşları ile atılganlık, sosyal normlara uyum ve sosyal sorumluluklara bağlilık düzeyleri arasında anlamlı bir ilişkinin olduğu tespit edilmiştir $(p<0,05)$. Spor yaşı değişkeni ile sportmenlik, kurallar ve yönetime saygı ve rakibe saygı düzeyleri arasinda herhangi bir anlamlı farklılık yoktur ( $>00,05)$. Anlamlı farklılığın hangi gruplar arasında olduğunu belirlemek için yapılan Bonferroni testi sonucuna göre atılganlık düzeylerine bakıldığında, spor yapmayanların atılganlık düzeyleri 6-10 yıl arası, 11-15 yıl arası ve 16 yıl ve daha fazla spor yapanlara göre daha düşüktür. 11-15 yıl arası spor yapanların atılganlık düzeyleri 0-5 yıl arası ve 6-10 yıl arası spor yapanlara göre daha yüksektir. 16 yıl ve üzeri spor yapanların atılganlık düzeyleri ise 0-5 yıl arası, 6-10 yıl arası ve 11-15 yıl arası spor yapanlara göre daha yüksektir. Ayrıca en yüksek atılganlık düzeyine sahip olanlar en fazla spor yapanlar iken en düşük atılganlık seviyesine sahip olan katılımclar ise spor yapmayan katılımcılardır. Sosyal normlara uyum düzeylerine bakıldığında, 11-15 yıl arası spor yapanların sosyal normlara uyum düzeyi 6-10 yıl arası spor yapanlara göre daha yüksektir. Sosyal sorumluluklara bağlılık düzeylerine bakıldığında ise, spor yapmayanların sosyal sorumluluklara bağlıllk düzeyi 0-5 yıl arası ve 610 yıl arası spor yapanlara göre daha düşüktür. 6-10 yıl arası spor yapanların sosyal sorumluluklara bağll1ık düzeyleri ise 16 yıl ve üzeri spor yapanlara göre daha yüksek tespit edilmiştir. 
Tablo 9. Katılımcıların Atılganlık, Sportmenlik ve Sportmenlik Ölçeğinin Alt Boyutlarından Aldıkları Puanların Branş Değişkenine Göre Kruskal Wallis Testi ile Karşılaştırılması

\begin{tabular}{|c|c|c|c|c|c|c|c|}
\hline Puan & Branş & n & $\begin{array}{c}\text { Siralar } \\
\text { Ort }\end{array}$ & $\mathbf{X}^{2}$ & sd & $p$ & Bonferroni \\
\hline \multirow{6}{*}{ Atılganlık } & Atletizm & 183 & 721,65 & & & & \\
\hline & Futbol & 151 & 643,08 & & & & $1>6$ \\
\hline & Voleybol & 128 & 692,85 & & & & $2>6$ \\
\hline & Mücadele Sp. & 168 & 666,85 & 39,881 & 5 &, $000^{*}$ & $3>6$ \\
\hline & Diğer & 183 & 629,38 & & & & $4>6$ \\
\hline & Yok & 441 & 548,36 & & & & $5>6$ \\
\hline \multirow{6}{*}{ Sportmenlik } & Atletizm & 183 & 721,99 & & & & \\
\hline & Futbol & 151 & 591,55 & & & & $1>4$ \\
\hline & Voleybol & 128 & 727,41 & & & & $1>5$ \\
\hline & Mücadele Sp. & 168 & 556,83 & 32,511 & 5 &, $000^{*}$ & $1>6$ \\
\hline & Diğer & 183 & 593,13 & & & & $3>4$ \\
\hline & Yok & 441 & 612,79 & & & & $6>4$ \\
\hline \multirow{6}{*}{$\begin{array}{l}\text { Sosyal } \\
\text { Normlara } \\
\text { Uyum }\end{array}$} & Atletizm & 183 & 657,77 & & & & $1>4$ \\
\hline & Futbol & 151 & 589,97 & & & & $3>2$ \\
\hline & Voleybol & 128 & 805,67 & 44,074 & 5 &, $000^{*}$ & $3>4$ \\
\hline & Mücadele Sp. & 168 & 569,20 & & & & $3>5$ \\
\hline & Diğer & 183 & 587,45 & & & & $3>6$ \\
\hline & Yok & 441 & 614,91 & & & & $6>4$ \\
\hline \multirow{6}{*}{$\begin{array}{l}\text { Kurallar ve } \\
\text { Yönetime Sayg1 }\end{array}$} & Atletizm & 183 & 732,89 & & & & $1>2$ \\
\hline & Futbol & 151 & 610,15 & & & & $1>4$ \\
\hline & Voleybol & 128 & 672,38 & 31,185 & 5 &, $000^{*}$ & $1>5$ \\
\hline & Mücadele Sp. & 168 & 531,55 & & & & $1>6$ \\
\hline & Diğer & 183 & 598,89 & & & & $3>4$ \\
\hline & Yok & 441 & 625,11 & & & & $6>4$ \\
\hline \multirow{6}{*}{$\begin{array}{l}\text { Sosyal Soruml. } \\
\text { Bağlllık }\end{array}$} & Atletizm & 183 & 712,76 & & & & $1>4$ \\
\hline & Futbol & 151 & 666,10 & & & & $1>6$ \\
\hline & Voleybol & 128 & 757,68 & 49,541 & 5 &, $000^{*}$ & $2>6$ \\
\hline & Mücadele Sp. & 168 & 605,67 & & & & $3>4$ \\
\hline & Diğer & 183 & 607,46 & & & & $3>6$ \\
\hline & Yok & 441 & 557,75 & & & & \\
\hline \multirow{6}{*}{ Rakibe Sayg1 } & Atletizm & 183 & 692,66 & & & & \\
\hline & Futbol & 151 & 580,76 & & & & $1>3$ \\
\hline & Voleybol & 128 & 563,27 & 24,460 & 5 &, $000^{*}$ & $1>4$ \\
\hline & Mücadele Sp. & 168 & 549,44 & & & & $5>4$ \\
\hline & Diğer & 183 & 639,49 & & & & $6>4$ \\
\hline & Yok & 441 & 659,87 & & & & \\
\hline
\end{tabular}

$*(p<0,05)$.

Tablo 9 incelendiğinde ise katılımcıların branşı ile atılganlık, sportmenlik, sosyal normlara uyum, kurallar ve yönetime sayg1, sosyal sorumluluklara bağlılık ve rakibe saygı düzeyleri arasında anlamlı bir ilişkinin olduğu tespit edilmiştir $(\mathrm{p}<0,05)$. Anlamlı farklılığın hangi gruplar arasında olduğunu belirlemek için yapılan Bonferroni testi 
sonucuna göre; atılganlık düzeylerine bakıldığında, hiçbir branşı olmayan katılımciların atılganlık düzeyleri atletizm, futbol, voleybol, mücadele sporları ve diğer branşlar ile uğraşan katılımcılara göre daha düşük bulunmuştur. Ayrıca en yüksek atılganlık düzeyine sahip olan katılımcların branşı atletizm iken en düşük atılganlık düzeyine sahip katılımclar ise herhangi bir spor dalıyla ilgilenmeyen katılımcılardır. Sportmenlik düzeylerine bakıldığında, branşı atletizm olan katılımcıların sportmenlik düzeyleri branşı mücadele sporları, diğer branşlar ve branşı olmayan katılımcılara göre daha yüksektir. Branşı mücadele sporları olan katılımcıların sportmenlik düzeyleri ise branşı voleybol olan ve herhangi bir branşla ilgilenmeyen katılımcllara göre daha düşüktür. Ayrıca en yüksek sportmenlik düzeyine sahip olan katılımcıların branşı voleybol ve atletizm iken en düşük sportmenlik düzeyine sahip olan katılımcıların branşı ise mücadele sporlarıdır. Sosyal normlara uyum düzeylerine bakıldığında, branşı atletizm ve voleybol olan ve herhangi bir branş ile ilgilenmeyenlerin sosyal normlara uyum düzeyi branşı mücadele sporları olan katılımclara göre daha yüksektir. Branşı voleybol olan katılımcıların sosyal normlara uyum düzeyi ise branşı futbol olan, diğer branşlarla ilgilenen ve hiç branşı olmayanlara göre daha yüksektir. Ayrıca en yüksek sosyal normlara uyum düzeyine sahip katılımcıların branşı voleybol ve atletizm iken en düşük düzeye sahip olanların branşı ise mücadele sporlarıdır. Kurallar ve yönetime saygı düzeylerine bakıldığında, branşı atletizm olanların kurallar ve yönetime saygı düzeyi branşı futbol, mücadele sporları, diğer branşlar olan ve herhangi bir branş ile ilgilenmeyenlere göre daha yüksektir. Branş1 voleybol olanların mücadele sporları ile ilgilenenlere göre ve hiçbir branşla ilgilenmeyenlerin mücadele sporları ile ilgilenenlere göre kurallar ve yönetime saygı düzeyleri daha yüksektir. Ayrıca en yüksek kurallar ve yönetime saygı düzeyine sahip olanların branşı atletizm iken en düşük düzeye sahip olanların branşı ise mücadele sporlarıdır. Sosyal sorumluluklara bağlılık düzeylerine bakıldığında, branşı atletizm olanların sosyal sorumluluklara bağlılık düzeyi mücadele sporları ile ilgilenenlere ve hiçbir branşla ilgilenmeyenlere göre daha yüksektir. Futbol ve voleybol ile ilgilenenlerin sosyal sorumluluklara bağlllık düzeyi hiçbir branşla ilgilenmeyenlere göre daha yüksektir. Voleybol branşı ile ilgilenenlerin sosyal sorumluluklara bağlılık düzeyi ise 
mücadele sporları ile ilgilenenlere göre daha yüksektir. Ayrıca en yüksek sosyal sorumluluklara bağlılık düzeyine sahip olanların branşı voleybol ve atletizm iken en düşük düzeye sahip olanlar ise hiçbir branşla ilgilenmeyen katılımcılardır. Rakibe saygı düzeylerine bakıldığında, branşı atletizm olanların rakibe saygı düzeyi voleybol ve mücadele sporları ile ilgilenenlere göre; diğer branşlarla ilgilenenlerin ve hiçbir branşla ilgilenmeyenlerin mücadele sporları ile ilgilenenlere göre daha yüksektir. Ayrıca en yüksek rakibe saygı düzeyine sahip olanların branşı atletizm iken en düşük düzeye sahip olanların branşı ise mücadele sporlarıdır.

\section{Tartışma ve Sonuç}

Spora katılımın atılganlık ve sportmenlik düzeyleriyle ilişkisini incelemek amacıyla yapılan araştırmanın bu bölümünde, elde edilen veriler ilgili literatür ışığında incelenmeye çalışılmıştır.

Atılganlık ölçeğinden elde edilen veriler katılımcıların genel olarak orta derecede çekingen olduklarını gösterirken sportmenlik ölçeğinden elde edilen veriler de katılımciların yüksek düzeyde sportmen davranışlar sergilediklerini göstermiştir. Bu sonuçlara bağlı olarak;

Araştırmanın 1. hipotezi ('Katılımcıların atılganlık düzeyleri ile sportmenlik düzeyleri arasında anlamlı ve pozitif yönlü bir ilişki vardır.'( $\left.\mathrm{H}_{1}\right)$ ) doğrultusunda yapılan testin bulgusuna göre (Tablo 4), katılımcların atılganlık düzeyleri ile sportmenlik düzeyleri arasında anlamlı $(\mathrm{p}<0,05)$ ve pozitif yönlü bir ilişki $(r=, 153)$ vardır. Bu bulgu, katılımcılarda atılganlık düzeyinin arttıkça sportmenlik düzeyinin de arttığını ortaya koymaktadır. Elde edilen bulgu araştırmanın hipotezini desteklemektedir. Literatür incelendiğinde Koç ve Güllü (2017)'nün, Erskine (1988)'nin, Chantal vd. (2005)'nin ve Trisnawati (2019)'nin yapmış oldukları çalışmalar araştırmamız bulguları ile uyumludur. Atılgan bireylerin hem kendi haklarını ve özgürlüklerini hem de karşısındaki kişilerin hak ve özgürlüklerini tanıyıp gözettiği için ahlaki olmayan davranışları uygulaması beklenmemektedir. Atılgan kişiler haksız rekabeti, ne olursa olsun kazanmayı ve ahlaki olmayan davranışları yapmayı tercih etmeyeceklerinden bu sonuçlar normal kabul edilebilir. Elde edilen ve literatürdeki bulgular doğrultusunda da 
atılganlık ile sportmenlik arasında pozitif yönlü ve anlamlı ilişkinin olduğu, yani atılgan olan bireylerin aynı zamanda sportmen davranışlar ortaya koydukları söylenebilir.

Araştırmanın 2. hipotezi ('Katılımcıların atılganlık düzeyleri ile cinsiyetleri arasında anlamlı bir ilişki vardır.'( $\left.\mathrm{H}_{2}\right)$ ) doğrultusunda yapılan testin bulgusuna göre (Tablo 5), katılımcıların atılganlık düzeyleri ile cinsiyetleri arasında erkekler lehine anlamlı $(\mathrm{p}<0,05)$ bir ilişki vardır. Elde edilen bulgu araştırmanın hipotezini desteklemektedir. Literatür incelendiğinde, Onyeizugbo (2003)'nun, Feingold (1994)'un ve Öztürk ve Bayazıt (2016)'ın yapmış olduğu çalışmalar araştırmamız bulguları ile paralellik göstermektedir. Parray ve Kumar (2016)'ın, Qadir ve Sugumar (2013)'ın ve Uzaina Parveen (2015)'in çalışmaları ise bulgularımızla benzerlik göstermemektedir. Alanyazındaki araştırmaların çoğunda elde edilen sonuçlar bulgularımıza paralel olmakla birlikte, araştırmalar arasındaki bu tutarsızlıkların sebebi toplumun cinsiyete yüklediği rol ve sorumluluklarla ilişkilendirilmiştir (Şahin, 2020). Toplumun, ailenin, arkadaşların veya antrenörlerin kişiler üzerine yüklemiş oldukları kimi sorumlulukların veya rollerin, o kişilerin atılganlık düzeyi üzerinde etkili olduğu söylenebilir. Bizim elde ettiğimiz bulgu, katılımcllarda cinsiyet değişkeninin atılganlık üzerinde anlamlı bir etkiye sahip olduğunu ortaya koymaktadır.

Araştırmanın 3. hipotezi ('Katılımcıların sportmenlik düzeyleri ile cinsiyetleri arasında anlamlı bir ilişki vardır.'( $\left.\mathrm{H}_{3}\right)$ ) doğrultusunda yapılan testin bulgusuna göre (Tablo 5), katılımcıların sportmenlik düzeyleri ile cinsiyetleri arasında kadınlar lehine anlamlı $(\mathrm{p}<0,05)$ bir ilişki vardır. Elde edilen bulgu araştırmanın hipotezini desteklemektedir. Literatür incelendiğinde Proios (2011)'un, Tsai ve Fung (2005)'un ve Efek (2019)'in yapmış oldukları çalışmalar bulgularımızı desteklemektedir. Shields vd. (2007)'nin, Miller, Roberts ve Ommundsen (2004)'in ve Efek, Sivrikaya ve Sadık (2018)'ın çalışmalar ise bulgularımızla benzerlik göstermemektedir. Araştırmalar arasındaki bu tutarsızlıkların sebebi spora katılım, spor yaşı, fiziki yaş, spora karşı tutum, ailevi ve sosyolojik etmenler olabilir. Bizim elde etmiş olduğumuz bulgu katılımcılarda cinsiyetin sportmenlik üzerinde anlamlı bir etkiye sahip olduğunu ortaya koymaktadır. 
Araştırmanın 4. hipotezi ('Spora katılım gösterenlerin atılganlık düzeyleri daha yüksektir.'( $\left.\mathrm{H}_{4}\right)$ ) doğrultusunda yapilan testin bulgusuna göre (Tablo 6), spor yapan katılımciların atılganlık düzeyleri daha yüksek bulunmuştur. Elde edilen bulgu araştırmanın hipotezini desteklemektedir. Literatür incelendiğinde, araştırmanın bulgularını destekleyen farklı araştırma bulguları mevcuttur. Akande vd. (2000)'nin yapmış olduğu çalışmada, sporun atılganlık düzeyini geliştirdiği belirtilmiştir. Etzel ve Mears (2004)'ın yaptığ 1 çalışmada, beden eğitiminin ve rekreasyon aktivitelerinin atılganlık düzeyini geliştirdiği belirtilmiştir. Newman (2003)'ın yapmış olduğu çalışmada, sporun atılganlık düzeyini geliştirdiği belirtilmiştir. Riykman vd. (1997)'nin yapmış olduğu çalışma, atılganlık ile spor becerileri arasında ilişkinin olduğunu ortaya koymuştur. Spora katılım yoluyla sosyalleşen, yenmeyi ve yenilmeyi tadan kişilerin daha atılgan olması olağan bir durumdur. Ayrıca spora katılım yoluyla paylaşmayı, yardım etmeyi, amaç edinmeyi, takım ruhunu, hak ve özgürlükleri, sosyal sorumlulukları ve beklentileri daha iyi öğrenen kişiler atılganlık konusunda gelişim göstermektedirler ve bu durum normal kabul edilebilir. Bizim bulgumuz da spor yapanlarda atılganlık düzeyinin daha yüksek olduğunu göstermektedir.

Araştırmanın 5. hipotezi ('Spora katılım gösterenlerin sportmenlik düzeyleri daha yüksektir.'(H35)) doğrultusunda yapılan testin bulgusuna göre (Tablo 6), spor yapan katılımcıların sportmenlik düzeyleri daha yüksektir. Elde edilen bulgu araştırmanın hipotezini desteklemektedir. Literatür incelendiğinde, araştırmanın bulgularını destekleyen farklı araştırma bulguları mevcuttur. Akandere, Baştuğ ve Güler (2009)'in, Bencik Kangal ve Arı (2013)'nın, Mouratidou, Goutza ve Chatzopoulos (2007)'un ve Ryska (2003)'nın çalışmaları bulgularımız ile benzerlik göstermektedir. Spor yoluyla kişiler yenmeyi, yenilmeyi, kimi zaman beklemeyi ve kimi zaman da öne çıkmayı pratiğe dökebilmektedirler. Yenmek kadar yenilmenin ve kazanmak kadar yarışmanın önemini spor yoluyla kavrayan bireyler sportmenlik davranışlarını geliştirebilmektedirler. Literatürle uyumlu bir şekilde elde etmiş olduğumuz bulgu da spor yapanlarda sportmenlik düzeyinin daha yüksek olduğunu göstermektedir. 
Araştırmanın 6. hipotezi ('Katılımcıların atılganlık düzeyleri ile yaşları arasında anlamlı bir ilişki vardır.'( $\left.\mathrm{H}_{6}\right)$ ) doğrultusunda yapılan testin bulgusuna göre (Tablo 7), katılımcıların atılganlık düzeyleri ile yaşları arasında anlamlı bir ilişki vardır $(\mathrm{p}<0,05)$. Elde edilen bulgu araştırmanın hipotezini desteklemektedir. Buna göre, katılımcıların en yüksek atılganlık düzeyleri 18 yaş ve altında olan gruptadır. Literatür incelendiğinde Gacar ve Coşkuner (2010)'in, Karataş ve Tabak (2009)'in ve Otrar ve Demirbilek (2013)'in çalışmaları bulgularımız ile uyumludur. Çam vd. (2010)'nin ve Ibrahim (2011)' in yapmış oldukları çalışmalar ise bulgularımızla benzerlik göstermemektedir. Literatürdeki araştırmaların sonuçları karşılaştıııldığında elde edilen sonuçlar tutarsızlık göstermektedir. $\mathrm{Bu}$ durumun sebebi araştırmalara katılan kişilerin sporcu olup olmaması, spor yaptıkları yıl değişkeni, eğitim düzeyleri, atılganlıklarını etkileyebilecek farklı değişkenlerin olması, yaş gruplarının birbirinden farklı olması gibi durumlar olabilir. Literatürde genel itibari ile yaş ile doğru orantılı olarak atılganlık düzeyi artmakta iken, çalışmamızda ise yaşlar arasında herhangi bir orantıda artış ya da azalma meydana gelmemiştir. Diğer yandan, yaş faktörü atılganlık durumuna etki eden önemli faktörlerden biri olarak bildirilmiştir. Gelişim dönemlerinde her yaş grubunun kendine has gelişimsel özellikleri bulunmaktadır ve kişinin atılganlık düzeyi de içinde bulunduğu yaş grubunun özelliklerine göre değişiklikler göstermektedir (Gündoğdu, Tüfekçi ve Çelebi, 2016). Dolayısıyla kişinin atılganlığını yaş faktörü etkileyebilmekte ve kişinin farklı demografik özellikleri yaş ve atılganlık faktörü ilişkisinde etkili olabilmektedir denilebilir. Elde ettiğimiz bulgu, yaşın atılganlık üzerinde etkili olduğunu göstermektedir.

Araştırmanın 7. hipotezi ('Katılımcıların sportmenlik düzeyleri ile yaşları arasında anlamlı bir ilişki vardır.'(H7)) doğrultusunda yapılan testin bulgusuna göre (Tablo 7), katılımcıların sportmenlik düzeyleri ile yaşları arasında anlamlı bir ilişki yoktur $(\mathrm{p}>0,05)$. Elde edilen bulgu araştırmanın hipotezini desteklememektedir. Literatür incelendiğinde Certel, Bahadır ve Çelik (2020)'in, Türkmen ve Varol (2015)'un ve Kayışoğlu vd. (2015)'nin yapmış oldukları çalışmalar bulgularımız ile paraleldir. 
Araştırmanın 8. hipotezi ('Katılımcıların atılganlık düzeyleri ile spor yaşları arasında anlamlı bir ilişki vardır.'(H8)) doğrultusunda yapılan testin bulgusuna göre (Tablo 8), katılımcıların atılganlık düzeyleri ile spor yaşları arasında anlamlı bir ilişki vardır $(\mathrm{p}<0,05)$. Elde edilen bulgu araştırmanın hipotezini desteklemektedir. Literatür incelendiğinde, Çam vd. (2010)'nin çalışması bulgularımız ile benzerdir. Ayrıca Kırımoğlu (2008)'nun yapmış olduğu çalışmada spor yaşı fazla olan katılımcların atılganlık düzeyi spor yaşı az olan katılımcılara göre daha yüksek bulunmuştur. Literatürde ve çalışmamızda elde edilen sonuçlar, atılganlık ile spor yapma süresi veya spor yaşı arasında pozitif yönlü bir ilişkinin olduğunu göstermektedir. Spor yoluyla deneyim ve tecrübe kazanan sporcular rakiplerine, taraftarlarına ve kamuoyuna karşı daha fazla sorumluluk hissedebilmektedirler. Spor yoluyla kazanılan bilgi ve deneyimler arttıkça bireyler kendilerinin ve karşısındakilerinin haklarını, özgürlüklerini, sorumluluklarını, tutumlarını ve davranışlarını daha iyi çözümleme fırsatı yakalayabilmektedirler. Buna göre, spor yapma süresi arttıkça atılganlık düzeyinin de arttı̆̆ı söylenebilir.

Araştırmanın 9. hipotezi ('Katılımcıların sportmenlik düzeyleri ile spor yaşları arasında anlamlı bir ilişki vardır.'( $\left.\mathrm{H}_{9}\right)$ ) doğrultusunda yapilan testin bulgusuna göre (Tablo 8), katılımcların sportmenlik düzeyleri ile spor yaşları arasında anlamlı bir ilişki yoktur $(p>0,05)$. Elde edilen bulgu araştırmanın hipotezini desteklememektedir. Literatür incelendiğinde, Yalçın, Tek ve Çetin (2020)'in, Özsarı vd. (2018)'nin ve Barkoukis ve Mouratidou (2015)'nun yapmış oldukları çalışmalar bulgularımız ile benzerlik göstermektedir. Literatürdeki birçok çalışmada, sporculuk tecrübesi veya spor yaşı ile sportmenlik arasında herhangi bir ilişkinin olmadığı görülmektedir. İlişkili çalışmaların ise bir kısmında küçük yaştaki katılımcıların yüksek; bir kısmında ise düşük sportmenlik düzeylerine sahip olduğu bildirilmiştir. Çalışmalar arasındaki bu tutarsızlıklar sportmenliğin spor yaşından kesin olarak etkilenmediği, sportmenlik üzerinde daha çok spordaki beklentilerin, rekabet düzeyinin, toplumsal yapının ve yetişme ortamının, eğitimin ve bazı ailevi sebeplerin etkili olduğu söylenebilir. Elde ettiğimiz bulgu, spor yaşının sportmenlik üzerinde etkili olmadığını ortaya koymaktadır.

Araştırmanın 10. hipotezi ('Katılımcıların atılganlık düzeyleri ile branşları arasında anlamlı bir ilişki vardır.'( $\left.\mathrm{H}_{10}\right)$ ) doğrultusunda yapılan 
testin bulgusuna göre (Tablo 9), katılımclların atılganlık düzeyleri ile branşları arasında anlamlı bir ilişki vardır $(\mathrm{p}<0,05)$. Elde edilen bulgu araştırmanın hipotezini desteklemektedir. Literatür incelendiğinde Çam vd. (2010)'nin yapmış olduğu çalışma bulgumuz ile uyum göstermektedir. Atan, Göçer ve Ünver (2018)'in, İnce (2017)'nin ve Yiğit, Ramzanoğlu ve Kavas (2017)'ın yapmış oldukları çalışmalar ise bulgularımıza benzer değildir.Çalışmalar arasındaki bu tutarsızlıklar çalışmalarda kullanılan branşların ve katılımcıların çeşitliliğinden kaynaklanmış olabilir. Spordaki beklentilerin, spor yapma amacinın, sporcuların amatör ya da profesyonel olmasının ve ailevi veya kültürel yapılardaki farklılıklar bu durumun ortaya çıkmasına sebep olmuş olabilir. Elde ettiğimiz bulgu, branşın atılganlık üzerinde etkili olmadığını ortaya koymaktadır.

Araştırmanın 11. hipotezi ('Katılımcıların sportmenlik düzeyleri ile branşları arasında anlamlı bir ilişki vardır.'(H11)) doğrultusunda yapılan testin bulgusuna göre (Tablo 9), katılımcıların sportmenlik düzeyleri ile branşları arasında anlamlı bir ilişki vardır $(\mathrm{p}<0,05)$. Elde edilen bulgu araştırmanın hipotezini desteklemektedir. Literatür incelendiğinde, Tsai ve Fung (2005)'un, Lee vd. (2007)'nin ve Kaye ve Ward (2010)'ın yapmış oldukları çalışmalar bulgularımızı desteklemektedir. Koç ve Seçer (2018)'in ve Akandere, Baştuğ ve Güler (2009)'in yapmış oldukları çalışmalar ise bulgularımızla uyumsuzdur. Çalışmalar arasındaki bu tutarsızlıklar katılımcıların farklı özelliklerinden (yaş, spor yaşı, kültürel ve ailevi yapi, spordan beklentiler ve spor yapma amacı gibi) kaynaklanmış olabilir. Elde ettiğimiz bulgu, branşın sportmenlik üzerinde etkili olduğu yönündedir. 
EXTENDED ABSTRACT

\title{
The Relationship between Participation in Sports and the Levels of Assertiveness and Sportsmanship
}

\author{
Engin Efek - Korkmaz Yiğiter \\ Burdur University- Yalova University
}

Psychology is a study field that included the study of human behavior, emotion, development, and more. Psychology is a branch of science that explains the reasons behind behavior. Physical health and mental health cannot be separated from each other. People can improve their physical appearance by participating in sports. This causes an increase of the psychological mood of the people. All people have factors such as anxiety, stress, depression at different levels and for different reasons. Therefore, the right level and method to be happy and healthy may vary from person to person.

In general, people shows many signal related to psychological mood that is good or bad. For example, symptoms of depression, high perceived stress levels, and low self-ratings of mental health reflect poor mental health and can challenge overall health, well-being, and quality of life (Himelhoch, at all, 2004). Physical and psychological health have both been shown to benefit from regular participation in physical activities. Health reasons are, however, not the only motives individuals have for taking part in sports. Motives related to appearance, competition and excitement, fun and enhanced competence, are a few other reasons (some psychological conditions such as anxiety, stress, phobia, depression etc.). It also has been suggested that the motives for participation influence sport participation time and adherence (Koivula, 1999).

Assertivenes is related to psychological mood. Having a good psychological mood helps to be assertive. If a person has an assertive skill, that person is a positive and confident. They know their own woth and believe in themselves. Assertive people adapt quickly to any new environment. They have no difficulty in socializing. They have no trouble socializing and make friends quickly. 
Assertiveness as, "behavior which enables people to stand up for themselves without undue anxiety, maximizes the reinforcement value of social interactions, and is positive, direct, courteous, and goaloriented" (Geisman, 1988). Assertiveness consist of multidimensional aspects of human expression, including behavior, cognition, and affect etc. Assertive people are able to express their emotions, defend their goals, and establish favorable interpersonal relationships in society they have been (Herzberger et al.,1984; Yong, 2010). In addition, the assertive people are not only a clear and open communicator but also one who is concerned with the feelings of other people. Therefore, they can make the distinction between being assertive and rude (Solberg et. al, 1995). People who speak assertively could explain the real problems in their relationship. Moreover, they have high self-esteem level therefore, they don't hesitate to participate in group activities. Assertiveness involves being able to speak up for oneself. Assertive communicators are often very dominant, independent, and competitive. Responsiveness involves being other-oriented. Responsive communicators are often very empathic, friendly, and helpful (Richmond \& Martin, 1998). Assertiveness is a skill concerning communication and social development, accordingly, it can be said that the recreational activity is one of the most important predictors of psychological parameters owing to its structure which contains communication and social relationships (Yiğiter, 2013). According to McCay and Keyes (2001) social competence includes five fields which are independence, assertiveness, social sensitivity, friendship building and social problem solving. Highly assertive individuals possess greater levels of internal locus of control and report experiencing fewer health problems than people with lower levels of assertiveness (Williams \& Stout, 1984).

In the light of all the above explanations, the purpose of the current study is to invesitgate the relationship between participation in sports and assertiveness and sportsmanship levels. For the research process, the survey model, which is one of the quantitative research types, was chosen. 1254 people participated in the research voluntarily and, they were selected using the random sample selection technique. The significance level was determined as $p<0.05$. The findings of the study showed that the participants were moderately shy, but had a high level 
of sportsmanship, and there was a positive and significant relationship between assertiveness and sportsmanship. In addition, there is a significant relationship between assertiveness and gender, age, sports age and branch variables. There is a significant relationship between sportsmanship and gender and branch variables. The current study showed that as assertiveness skill of the people increases, sportsmanship of the people also increases, and gender and branch are determinants on assertiveness and sportsmanship. The assertiveness and sportsmanship levels of individuals who participated in various sports could be increased. In addition, while age and sports age are determinants on assertiveness, they are not effective on sportsmanship. Presumably, many other parameters could effect on the assertiveness skill and sportsmanship behavior. There future research can expand the study samples.

\section{Kaynakça/References}

Akande, A., Van Wyk, C. ve Osagie, J. E. (2000). Importance of exercise and nutrition in the prevention of illness and the enchancement of health. Journal article by Education, 120(4), 758-772.

Akandere, M., Baştuğ, G. ve Güler, E. D. (2009). Orta öğretim kurumlarında spora katılımın çocuğun ahlâki gelişimine etkisi. Niğde Üniversitesi Beden Eğitimi ve Spor Bilimleri Dergisi, 3(1), 59-68.

Altınkök, M., Kayışoğlu, N. B., Temel, C. ve Yüksel, Y. (2015). Ortaokul öğrencilerinin beden eğitimi dersi sportmenlik davranışlarının incelenmesi: Karabük ili örneği. International Journal Of Social Sciences And Education Research, 1(3), 1045-1056.

Atan, T., Göçer, S. ve Ünver, Ş. (2018). Farklı branşlardaki erkek ve kadın sporcuların atılganlık ile problem çözme becerileri arasındaki ilişki. Uluslararası Sosyal Araştırmalar Dergisi, 11(60), 1359-1366. Doi: 10.17719/jisr.2018.2882.

Barkoukis, V. ve Mouratidou, K. (2015). Achievement goals and sportspersonship orientations in team sports. The moderating role of demographic characteristics. Ethics in Progress, 6(2), 74-92. https://doi.org/10.14746/eip.2015.2.6 
Bencik Kangal, S. ve Arı, M. (2013). Üstün yetenekli ve normal gelişim gösteren çocukların ahlâki yargı düzeyine yaratıcı drama programlarının etkisinin incelenmesi. Eğitim ve Bilim, 38(170), 308-320.

Certel, Z., Bahadır, Z. ve Çelik, B. (2020). Ortaokul öğrencilerinin beden eğitimi dersi sportmenlik davranışları. Spor ve Performans Araştırmaları Dergisi Journal of Sports and Performance Researches, 11(3), 231-244. Doi: 10.17155/omuspd.676577.

Chang, P. J., Wray, L. ve Lin, Y. (2014). Social relationships, leisure activity, and health in older adults. Health Psychology, 33(6), 516-523. Doi:10.1037/hea0000051.

Chang, Y. C., Yeh, T. M., Pai, F. Y. ve Huang, T. P. (2018). Sport activity for health! The effects of karate participants' involvement, perceived value, and leisure benefits on recommendation intention. International Journal Of Environmental Research And Public Health, 15(5), 953. Doi: 10.3390/ijerph15050953.

Chantal, Y., Robin, P., Vernat, J. P. ve Bernache Assollant, I. (2005). Motivation, sportspersonship, and athletic aggression: A mediational analysis. Psychology of Sport and Exercise, 6, 233-249. https://doi.org/10.1016/j.psychsport.2003.10.010.

Cremades, J. G. (2014). Becoming a sport, exercise, and performance psychology professional: A global perspective. New York: Psychology Press.

Çaha, Ö. (1999). Spora yaslanarak bir nefes alma. Ankara: Beta.

Çam, İ. Ö., İlknur, Y., Çetin, B., Salman, M. ve Çekin, R. (2010). Spor Yüksekokulu öğrencilerinin değişik demografik özelliklere göre atılganlık düzeylerinin araştırılması. Celal Bayar Üniversitesi Beden Eğitimi ve Spor Bilimleri Dergisi, 5(2), 46-51.

Efek, E. (2019). Farklı fakültelerde eğitim gören ve spor yapan düzce üniversitesi öğrencilerinin ahlaki gelişim düzeyleri ile spora yönelik tutumları arasındaki ilişkinin incelenmesi. Journal of Social and Humanities Sciences Research, 6(43), 2967-2975. Doi: http://dx.doi.org/10.26450/jshsr.1438.

Efek, E. (2020). Spor ve dikkat. (Ed. Doç. Dr. Özgür Karataş). Spor Bilimleri Alanında Akademik Araştırmalar. (s.39-69). Ankara: Duvar Yayınları.

Efek, E., Sivrikaya, Ö. ve Sadık, R. (2018). Spor bilimleri alanında okuyan üniversite öğrencilerinin ahlaki gelişim düzeyleriyle spor tutumları arasındaki ilişkinin incelenmesi. Journal of Social And Humanities Sciences Research (JSHSR), 5(29), 3895-3903. Doi: 10.26450/jshsr.828. 
Erkal, M. (1981). Sosyolojik açıdan spor. İstanbul: Filiz Kitabevi.

Erskine, R. G. (1988). Ego structure, intrapssychic function and deffense mechanisms: A commentary on Eric Berne's original therotical concepts. Transactional Analysis Journal, 18(1), 15-19.

Ertüzün, E., Hadi, G. ve Fidan, E. (2020). Spor merkezine üye bireylerin rekreasyon fayda düzeylerinin bazı değişkenlere göre incelenmesi. Journal of Sports and Performance Researches, 11(3), 221-230. Doi: 10.17155/omuspd.657210.

Etzel-Wise, D. ve Mears, B. (2004). Adapted Physical Education and Therapeutic Recreation in Schools. Journal Article by Intervention in School \& Clinic, 39(4), 223-232.

Feingold, A. (1994). Gender differences in personality: A meta-analysis. Psychological Bulletin, 116(3), 429-456.

Gacar, A. ve Coşkuner, Z. (2010). Güreşçilerin atılganlık düzeylerinin bazı degişkenler açısından incelenmesi. e-Journal of New World Sciences Academy, 5(3), 195-203.

Geisman, C. (1988). Becoming and remaining assertive. Psychological Reports, 63, 596-605.

Gönener, A. (2020). Effect of sport education on stress and assertiveness of middle school students. International Education Studies, 13(5), 108-116. Doi:10.5539/ies.v13n5p108.

Green, F. T. (1997). Sportsmanship education in secondary school athletics: Athletic directors' perspectives. Doctorate Thesis. Texas A \& M University, US.

Gündoğdu, C, Tüfekçi, Ş. ve Çelebi, E. (2016). Gençlik merkezlerine üye olan gençlerin atılganlık düzeylerinin incelenmesi. İnönü Üniversitesi Beden Eğitimi ve Spor Bilimleri Dergisi, 3(1), 1-9.

Herzberger, S.D., Chan, E. ve Katz, J. (1984). The development of an assertiveness selfreport inventory. Journal of Personality Assessment, 48(3), 317-323.

Himelhoch, S., Lehman, A., Kreyenbuhl, J. et al. (2004). Prevalence of chronic obstructive pulmonary disease among those with serious mental illness. American Journal of Psychiatry, 161, 2317.

Ibrahim, S. A. E. A. (2011). Factors Affecting assertiveness among student nurses. Nurse Education Today, 31(4), 356-360. Doi: 10.1016/j.nedt.2010.07.006. 
İnce, G. (2017). Farklı spor branşlarıyla uğraşan bedensel engelli bireylerin atılganlık durumlarının karşılaştırılması. Uls Spor Egz \& Ant Bil Dergisi, 1(2), 1-7. https://doi.org/10.18826/useeabd.282144.

Karafil, A. Y., Atay, E., Ulaş, M. ve Melek, C. (2017). Spora katılımın beden eğitimi dersi sportmenlik davranışları üzerine etkisinin araştırılması. СВÜ Beden Ĕ̆itimi ve Spor Bilimleri Dergisi, 12(2), 1-11.

Karataş, S. ve Tabak, N. (2009). Okul öncesi öğretmen adaylarının atılganlık düzeylerinin bazı sosyodemografik özellikler açısından incelenmesi. Uşak Üniversitesi Sosyal Bilimler Dergisi, 2(2), 143-159.

Kaye, M. P. ve Ward, K. P. (2010). Participant-related differences in high school athletes' moral behavior. Athletic Insight: The Online Journal of Sport Psychology, 12(1), 1-17.

Kırımoğlu, H. (2008). Türkiye 13 yaş altı badminton şampiyonasına katılan sporcu öğrenciler ile sporcu olmayan öğrencilerin atılganlık düzeylerinin karşılaştııılması. S.Ü. BES Bilim Dergisi, 10(2), 1-9.

Koç, Y. ve Güllü, M. (2017). Lise öğrencilerinin beden eğitimi dersi sportmenlik davranışlarının bazı değişkenlere göre incelenmesi. Spormetre, 15(1), 19-30.

Koç, Y. ve Seçer, E. (2018). Spor bilimleri alanında eğitim gören üniversite öğrencilerinin sportmenlik davranışları ile saygı düzeyleri arasındaki ilişkinin incelenmesi. CBÜ Beden Ĕ̆itimi ve Spor Bilimleri Dergisi, 13(2), 247-259. Doi: 10.33459/cbubesbd.383027.

Koivula, N. (1999). Sport participation: Differences in motivation and actual participation due to gender typing. Journal of Sport Behavior, 22, 360380.

Lee, M. J., Whitehead, J. ve Ntoumanis, N. (2007). Development of the attitudes to moral decisionmaking in youth sport questionnaire (AMDYSQ). Psychology of Sport and Exercise, 8(3), 369-392. https://doi.org/10.1016/j.psychsport.2006.12.002.

Mathner, R. P., Martin, C. L., Tatum, S. A. ve Chouti, D. (2010). The effects of a sportsmanship educational program on the behavior of college intramural sports participants. Recreational Sports Journal, 34(2), 119128. Doi: $10.1123 /$ Rsj.34.2.119.

McCay, L. ve Keyes, D. (2001). Developing social competence in the inclusive primary classroom. Childhood Education, 78(2), 70-78.

Méndez-Giménez, A, Fernández-Río, J. ve Méndez-Alonso, D. (2015). Sport education model versus traditional model: Effects on motivation and 
sportsmanship. Revista Internacional de Medicina y Ciencias de la Actividad Fisica y del Deporte, 15, (59), 449-466. http://dx.doi.org/10.15366/rimcafd2015.59.004.

Miller, B. W., Roberts, G. C. ve Ommundsen, Y. (2004). Effect of motivational climate on sportspersonship among competitive youth male and female football players. Scandinavian Journal of Medicine $\mathcal{E}$ Science in Sports, 14(3), 193-202. Doi: 10.1111/j.1600-0838.2003.00320.x.

Mouratidou, K., Goutza, S. ve Chatzopoulos, D. (2007). Beden eğitimi ve ahlâki gelişim: Lise öğrencilerinin beden eğitimi yoluyla ahlâki akıl yürütmeyi teşvik eden bir müdahale programı. Avrupa Beden Eğitimi Dergisi, 13(1), 41-56. https://doi.org/10.1177/1356336X07072675.

Newman, R. (2003). It pays to be personal: Baseball and product endorsements. Nine, 12(1), 25-42.

Onyeizugbo, E. U. (2003). Effects of gender, age, and education on assertiveness in a Nigerian sample. Psychology of Women Quarterly, 27(1), 12-16. https://doi.org/10.1111/1471-6402.t01-2-00002.

Otrar, M. ve Demirbilek, M. (2013). Ebeveynleri birlikte olan ergenler ile parçalanmış olan aileye sahip ergenlerin benlik saygıları ve atılganlık düzeyleri üzerine bir inceleme. Ĕ̆itimde Politika ve Analizi Dergisi, 2(2), 21-40.

Özsarı, A, Demïrel, H., Altın, M, Yalçın, Y. ve Demïr, H. (2018). Kadın basketbolcuların sportmenlik yönelimleri. Türk Spor Bilimleri Dergisi, 1(2), 66-71.

Öztürk, A. ve Bayazıt, B. (2016). Beden eğitimi ve spor yüksekokulu öğrencilerinin atılganlık düzeyleri ve problem çözme becerilerinin incelenmesi (Kocaeli Üniversitesi Rekreasyon Bölümü Örneği). Akademik Sosyal Araştırmalar Dergisi, 4(25), 332-340. Doi: 10.16992/ASOS.1086.

Parray, W. M. ve Kumar, S. (2016). Assertiveness among undergraduate students of the University. The International Journal of Indian Psychology, 4(1), 283-291.

Richmond, V. P. ve Martin, M. M. (1998). Sociocommunicative style and sociocommunicative orientation. In J. C. McCroskey, J. A. Daly, M. M. Martin, \& M. J. Beatty (Eds.) Communication and personality: Trait perspectives (p.133-146). Cresskill, NJ: Hampton Press. 
Proios, M. (2011). Relationship between student perceived conduct in physical education settings and "Unfair" play. International Journal of Applied Sports Sciences, 23(2), 421-440. Doi: 10.24985/ijass.2011.23.2.421.

Proios, M., Doganis, G. ve Proios, M. (2006). Form of athletic exercise, school environment, and sex in development of high school students' sportsmanship. Perceptual and Motor Skills, 103(1), 99-106. https://doi.org/10.2466/pms.103.1.99-106.

Qadir, A. S. ve Sugumar, V. R. (2013). A study on assertiveness among adolescents. Golden Research Thoughts, 3(4), 1- 4.

Rathus, S. A. (1973). A 30-item schedule for assessing assertive behavior. Behavior Therapy, 4(3), 398-406. https://doi.org/10.1016/S00057894(73)80120-0.

Richard, M. Ryckman., Butler, J.C., Thornton, B. ve Lindner, M.A. (1997). Assessment of physique subtype stereotypes. Genetic, Social, and General Psychology Monographs, 123, 1.

Ryan, J. G. ve Dzewaltowski, D. A. (2002). Comparing the relationship between different types of self-efficacy and physical activity in youth. Health Education and Behavior, 29, 491. Doi: $10.1177 / 1090198102029004008$.

Ryska, T. A. (2003). Sportsmanship in young athletes: The role of competitiveness, motivational orientation and perceived purposes of sport. Journal of Psychology, 137, 273-293. Doi: 10.1080/00223980309600614.

Sezen Balçıkanll, G. (2010). Çok Boyutlu Sportmenlik Yönelimi Ölçeği'nin Türkçe uyarlaması: Geçerlik ve güvenirlik çalışması. Gazi Beden Eğitimi ve Spor Bilimleri Dergisi, 15(1), 1-10.

Shields, D., La Voi, N., Bredemeier, B. ve Power, F. (2007). Predictors of poor sportpersonship in youth sports: Personal attitudes and social influences. Journal of Sport \& Exercise Psychology, 29(6), 747-762. Doi: 10.1123/jsep.29.6.747.

Soldberg, V., Fischer, A., Good, G., Brown, S. ve Nord, J. (1995). Career decision making and career search activities: Relative effects of career search self-efficacy and human agency. Journal of Counseling Psychology, 42, 448-455.

Sunay, H. (2017). Spor yönetimi. (3. baskı). Ankara: Gazi Kitabevi. 
Şahin, G. (2020). Öğretmenlerin kişilik özellikleri ile atılganlıkları arasındaki ilişkide pozitif psikolojik sermayelerinin araci rolü. Doktora Tezi. Hacettepe Üniversitesi, Eğitim Bilimleri Enstitüsü, Ankara.

Trisnawati, K. A. (2019). Mengatasi perilaku terisolir remaja menggunakan konseling behaviour teknik assertive training. Daiwi Widya Journal Pendidikan, 6(1), 49-60.

Tsai, E. ve Fung, L. (2005). Sportspersonship in youth basketball and volleyball players. The Online Journal of Sport Psychology, 7(2), 37-46.

Türkmen, M. ve Varol, S. (2015). Beden eğitimi ve spor dersinin ortaokul öğrencileri üzerinde sportmenlik davranışı oluşturma etkisinin belirlenmesi: Bartın İl örneği. International Journal of Contemporary Educational Studies (IntJCES), 1, 42-64.

Vallerand, R. J., Briere, N. M., Blanchard, C. ve Provencher, P. (1997). Development and validation of the multidimensional sportspersonship orientations scale. Journal of Sport \& Exercise Psychology, 19(2), 197-206.

Uzaina Parveen, A. (2015). Study of relationship between mental health and assertiveness among adolescents. The International Journal of Indian Psychology, 3(1), 98, 103. Doi: 10.25215/0301.085.

Voltan, A. N. (1980). Rathus Atılganlık Envanteri geçerlik ve güvenirlik çalışması. Psikoloji Dergisi, 10, $23-25$.

Williams, J. M. ve Stout, J. K. (1984). The effect of high and low assertiveness on locus of control and health problems. The Journal of Psychology, 119(2), 169-173.

Wolpe, J. ve Lazarus, A. A. (1966). The commonwealth and international library. Mental Health and Social Medicine Division. Behavior Therapy Techniques: A guide to the treatment of neuroses. Oxford, New York: Pergamon Press.

Yalçın, Y. G., Tek, T. ve Çetin, M. Ç. (2020). Amatör olarak spor yapan üniversite öğrencilerinin sportmenlik yönelimlerinin incelenmesi. Türk Spor Bilimleri Dergisi, 3(1), 29-34.

Yalız Solmaz, D. ve Bayrak, C. (2016). Beden eğitimi dersindeki fiziksel etkinlik oyunlarını ilköğretim öğrencilerinin karakter gelişimleri üzerindeki etkisi. Hacettepe Üniversitesi Ĕ̆itim Fakültesi Dergisi (H. U. Journal of Education), 31(4), 644-656. doi: 10.16986/HUJE.2016015695.

Yapan, H. T. (2007). Spor ahlakı. Gaziantep: Merkez Ofset. 
Yeh, T. M., Chang, Y. C. ve Lai, M. Y. (2017). The relationships among leisure experience, leisure benefits and leisure satisfaction of you bike users. The Journal of Hospitality Leisure Sport and Tourism, 12, 67-97. Doi: 10.29429/JSLHR.201706_12(2).05.

Yetim, A. (2000). Sporun sosyal görünümü. Gazi Beden Ĕ̆itimi ve Spor Bilimleri Dergisi, 5(1), 63-72.

Yong, F. (2010). A Study on the assertiveness and academic procrastination of English and communication students at a private university. American Journal of Scientific Research, 9, 62-72.

Yiğit, Ş., Ramzanoğlu, F. ve Kavas, E. T. (2017). An examination of levels of assertiveness in students who do sport in different branches in university. Akademik Sosyal Araşttrmalar Dergisi, 5(60), 353-361. Doi: http://dx.doi.org/10.16992/ASOS.13075.

Yiğiter, K. (2013). Improving the nursing students' assertiveness skills by participating in recreational physical activities. International journal of sport studies, 3(3), 258-262.

Zorba, E. ve Göksel, A. G. (2016). Türkiye'deki plaj hentbolu sporcularının spora başlamasına etki eden unsurlar ve spordan gelecek beklentileri. Journal of Human Sciences, 13(2), 3092-3101. Doi: 10.14687/jhs.v13i2.3773.

\section{Kaynakça Bilgisi / Citation Information}

Efek, E. ve Yiğiter, K. (2021). Spor katılımının atılganlık ve sportmenlik düzeyleri ile ilişkisi. OPUS- Uluslararası Toplum Araştırmaları Dergisi, 18(43), 6732-6763. DOI: 10.26466/opus.945546. 